\title{
Advanced Characterization of Natural Biofilm on Nanofiber Scaffold
}

\author{
L. SVOBODOVÁ ${ }^{1,2}$, T. LEDERER ${ }^{2}$, P. ROSICKÁ ${ }^{2,3}$, P. SVOBODA $^{3}$, L. NOVÁK $^{4}$, \\ J. DOSTÁLKOVÁ ${ }^{5}$, V. JIRKÜ
}

${ }^{1}$ Faculty of Mechanical Engineering, Department of Material Science, Technical University of Liberec, Liberec, Czech Republic, ${ }^{2}$ Institute for Nanomaterials, Advanced Technology and Innovation, Technical University of Liberec, Liberec, Czech Republic, ${ }^{3}$ Faculty of Mechatronics, Informatics and Interdisciplinary Studies, Technical University of Liberec, Liberec, Czech Republic, ${ }^{4}$ Aqua4you s.r.o., Božtěšice, Ústí nad Labem, Czech Republic, ${ }^{5}$ Department of Biotechnology, Institute of Chemical Technology, Prague, Czech Republic.

Received June 26, 2019

Accepted October 29, 2019

\begin{abstract}
Summary
Nanofiber scaffolds provide numerous advantages over common carriers engineered for microorganisms. The most important advantage is an increased speed of primary surface colonization (up to four times faster), which shortens the time required for the areal biofilm formation and optimum performance of attached microorganisms (higher efficiency of biological activity of up to twice as fast). Image analysis predicts early formation of biofilm even in beginning stages; analysis of biofilm reveals the different structures of bacterial colonies on both scaffolds (higher porosity, size, and number of bacterial colonies on nanofiber's surface). The image analysis correlates well with determinations of dry matter (linear correlation of 0.96 ) and proteins (linear correlation of 0.89).
\end{abstract}

\section{Key words}

Biofilm formation and development • Image analysis of bacterial biofilm • Microbial immobilization • Nanofiber scaffold

\section{Corresponding author}

L. Svobodová, Faculty of Mechanical Engineering, Department of Material Science, Technical University of Liberec, Studentská 2, 46117 Liberec 1, Czech Republic. E-mail: lucie.svobodova@tul.cz

\section{Introduction}

The biofilm technology is widely utilized in many areas to produce a range of beneficial products (food biotechnology, pharmacology, microbiology, medicine) (Janoušková 2018), on the other hand, the bacteria living in biofilm are more resistant to antibiotics substances (Singh et al. 2017), which is a huge problem at this time including the treatment of hospital waste water. The characterization of the biofilm and the early knowledge of its structure and properties can be valuable in predicting the biofilm states and growth efficiency, and hence the increase in efficiency of the biological process in general (Haider et al. 2018). Cell cluster size and the amount of unoccupied space on the surface, for example, are associated with changes in population and nutrient status (Costa et al. 2013), while cluster shape is connected with system hydrodynamics (Lewandowski and Beyenal 2013, Li et al. 2019). These findings underscore the need for a precise and timely description of the structure and development of biofilms. Better characterization of biofilm properties may also improve our understanding of processes and provide quantitative descriptions of the system.

Approaches used to characterize a range of wellknown biofilms have previously been reviewed (Costa et al. 2013). Examples of methods describing amounts of total biofilm include, for example, dry weight, volatile solids, or measuring specific biofilm constituents (e.g., exopolysaccharides, proteins, total cell count) or cellular components (e.g., peptidoglycane, lipopolysaccharides, lipids). The main disadvantage of these parameters for biofilm characterization is that their estimation includes not only active microorganisms but also inert mass, exopolymers, and adsorbed organic matter. In recent years, quantitative image analysis of microbial aggregates has burgeoned (Azeredo et al. 2017). The use 
of quantitative digital image analysis for advanced surface structure analysis (Li et al. 2019) provides a number of benefits over standard methods (such as the determination of dry matter or proteins), including significantly higher range of biofilm characteristics, greater speed and more objective evaluation, increased accuracy when processing large amounts of data, and no need for further analytical training. In biological practice, its non-invasive character is of special advantage (O’Gorman et al. 2008, Sonka et al. 2007, Wu et al. 2008).

The surface (substrate, scaffold, carrier material etc.) for bacterial biofilm colonization is a dominant factor in the biological process (Janoušková 2018). The influence of the scaffold surface-structure on bacterial biofilm stability has been the subject of a number of studies (Hadjiev et al. 2007, Jurecska et al. 2013). All of which confirm that surface roughness improves biofilm development and is a more significant factor than the surface's other physical and chemical properties. The relative importance of surface roughness depends a great deal on system conditions. There are many other examples demonstrating that strong shear stress results in a more rigid and homogeneous biofilm (Wang et al. 2014). Moreover, the effect of changes in environmental conditions (e.g. temperature, $\mathrm{pH}$, nutrient concentration, metabolic products, and toxic substances) is less impactful on immobilized biomass than on suspended microorganisms (Sipma et al. 2010). The initial stages of biofilm formation also play an important role and have a considerable impact on the structure and physicochemical properties of the 'mature' biofilm (Habimana et al. 2014).

In this paper, we used the image analysis method to reveal the nature of biofilm formation on two different surfaces through optical microscopy with non-invasive procedure. The first has been the polymer structure of high-density polyethylene with a relatively smooth surface (commercially known as AnoxKaldnes ${ }^{\mathrm{TM}}$, most often used as a carrier in wastewater treatment plant). The second surface was formed by polyurethane nanofibers. The research was carried out with the aim of uncovered primary biofilm formation even within hours after exposure with the help of the image analysis of native sample, moreover, analysis can display the different structures of bacterial colonies on both scaffolds (porosity, size). Nanofiber scaffold displays rapid colonization and the final biofilm achieve higher efficiency of biological activity.

\section{Materials and Methods}

\section{Bacterial strain and media used}

In this study, we used the bacterial strain Rhodococcus erythropolis (CCM 2595 IN) as it is able to utilize high levels of phenols as its sole source of carbon and energy. We used a traditional basal salt medium for initial cultivation, the optical density of the medium (with the bacteria) being set to 0.3 (wavelength $420 \mathrm{~nm}$, using a DR $6000^{\mathrm{TM}}$ UV VIS spectrophotometer, Hach Lange, Germany, corresponding to approximately $10^{6} \mathrm{CFU} / \mathrm{ml}$ ) for both types of carrier at the start of the experiment. We added macronutrients in the form of mineral salts at levels corresponding to $60 \mathrm{mg} / 1 \mathrm{~K}_{2} \mathrm{HPO}_{4}$ and $100 \mathrm{mg} / \mathrm{l}$ $\mathrm{NH}_{4} \mathrm{Cl}$, with salinity being set at around $7 \mathrm{mS} / \mathrm{cm}$ using $\mathrm{NaCl}$. The wastewater used for the experiments was taken from a groundwater remedial pumping system in the area of a former phenol production site. The groundwater at this site is highly contaminated by phenols, and especially by cresols, which represent not readily biodegradable contaminants and are the reason for the high values of hydraulic residence time (HRT). The wastewater contained phenol (172-1642 mg/l), cresols (59-1110 mg/l), dimethylphenol (48-285 mg/l), and higher phenols (13-19 mg/l), cumulatively evaluated as having a chemical oxygen demand (COD) of around 1700-6500 mg/l.

\section{The scaffold for cell population}

We tested two types of scaffolds, the first was the commercially available AnoxKaldnes (AK) type of K3 (AnoxKaldnes ${ }^{\mathrm{TM}}$ ) with a polymer structure of high-density polyethylene (Fig. 1a, the maximum specific protected surface of the AK carrier is approximately $500 \mathrm{~m}^{2} \mathrm{~m}^{-3}$ ).

The second scaffold were nanofiber threads (Fig. 1b, the specific surface of the NFs is $670 \mathrm{~m}^{2} \mathrm{~m}^{-3}$ when the morphology of the nanofibers, i.e., the specific surface of the NF layer covering the surface of the basic polypropylene fiber was taken into account for the calculation) developed at Technical University of Liberec (Jirsák et al. 2005). The NF thread comprised of three parts (Fig. 1c), a polypropylene fibers with a coating of electrospun polyurethane nanofibers (diameter approximately $260 \mathrm{~nm}$ ) are bound together with two polyethylene fibers that protect the thread against friction during processing and against NF disintegration during subsequent application (Jirsák et al. 2011). The threads are tightly wound on metal grids as fixed-bed (size of $10 \times 10 \mathrm{~cm}$, Fig. 1d). 


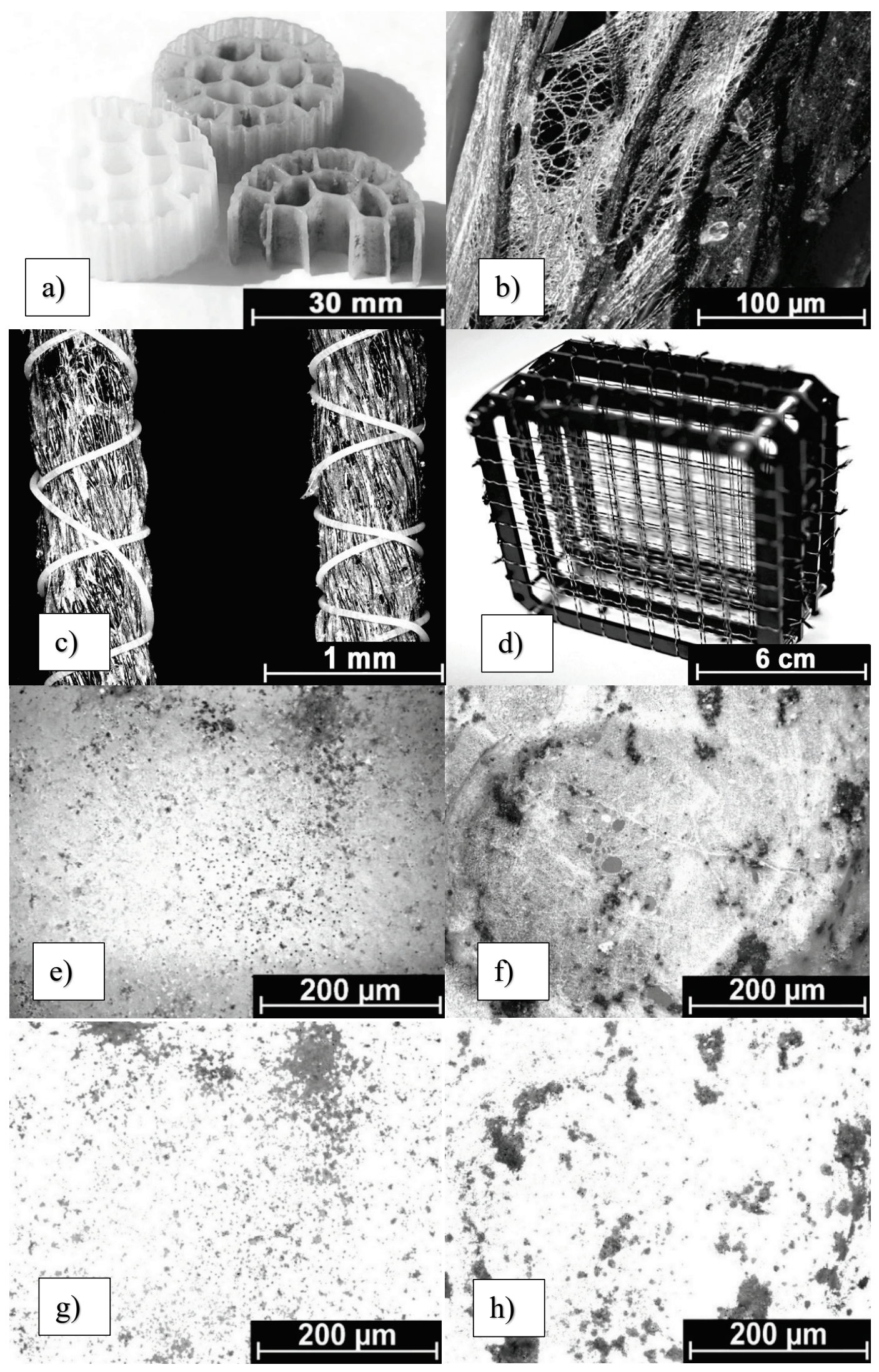

Fig. 1. a) the commercial AK K3 carrier (one new and one previously used structure, and a sectional view of a carrier for microscopic evaluation); b) detail of electrospun nanofibers; c) nanofiber threads wrapped with protective surface fibers; d) the metal-frame bound with nanofiber threads; e) microscopic image of the commercial AK K3 surface with biofilm; f) microscopic image of the NF scaffold biofilm; g) extracted layer with biofilm following image segmentation of the commercial AK K3 substrate; and $\mathbf{h}$ ) extracted layer with biofilm following image segmentation of the NF scaffold. For images (e) - (h) white areas correspond to the scaffold (substrate), grayscale match biofilm (AK = AnoxKaldnes scaffold, NF = nanofiber scaffold). 
Both scaffolds are prepared using water stable and non-biodegradable polymers thus their longevity is virtually unlimited.

\section{Reactors}

We used a laboratory-based bioreactor that allowed continuous biomass cultivation in the mixing reactor without the biomass recirculation (chemostat regime, where a given cell population can be grown in a physiological steady state, constant culture volume, cell density, growth rate, nutrient and dissolved oxygen concentration, $\mathrm{pH}$ and others). The reactor volume (3000 $\mathrm{ml}$ in glass beaker) controlled through peristaltic pump and artificial overflow, the HRT was set for 4-12 days (the culture volume was kept constant). An aerator was placed at the bottom of each reactor (set for middle bubble aeration, $6.5 \mathrm{~L}$ (air)/h/L(medium) airflow rate, $8-11 \mathrm{mg} / \mathrm{l}$ dissolved oxygen concentration in the reactor) to ensure turbulent water flow and sufficient homogeneity and oxygenation of the mixture. Each type of carrier was placed in a separate bioreactor, however, the above parameters were kept for both reactors. The metal grids with the tightly wound NF threads was submerged directly into the reactor, the surface area of the substratum in the reactor with the NF scaffold was $0.67 \mathrm{~m}^{2}$, the surface area loading rates were $0.7-6.8 \mathrm{~g} / \mathrm{m}^{2} /$ day. The AK bioreactor with $\mathrm{K} 3$ was operated as moving bed biofilm reactor, the AK bioreactor was filled to $25 \%$ of the reactor volume (i.e., the minimum proposed) so the surface area of this substratum in the reactor was $0.45 \mathrm{~m}^{2}$, the surface area loading rates were $0.9-10.2 \mathrm{~g} / \mathrm{m}^{2} /$ day.

\section{Approach to determining concentration of total protein}

Total protein levels (intra and extracellular) were determined using the Lowry method. We placed samples of each scaffold with bacterial biofilm into a test tube, along with $5 \mathrm{ml}$ of sterile water, and subjected it to $60 \mathrm{~min}$ sonication at $60^{\circ} \mathrm{C}$, thereby causing the biofilm to break away from the scaffold as well as cell lysis. The effects of interferences with sugars or lipids was ameliorated by diluting the samples. Lowry reagents were added to the test tube and the sample was incubated for $10 \mathrm{~min}$ at room temperature, following which $1 \mathrm{ml}$ of Folin-Ciocalteu reagent was added and the sample left at $25^{\circ} \mathrm{C}$ for $30 \mathrm{~min}$. The concentration of total protein was determined in the aqueous solution at $600 \mathrm{~nm}$ using a DR $6000^{\mathrm{TM}}$ UV-VIS spectrophotometer (Hach Lange, Germany).

\section{Determination of dry matter}

Dry matter was determined according to the standard DIN EN 14346 (838016) methodology (establishing the proportion of dry matter and water content), with sample drying set at $105^{\circ} \mathrm{C}$.

\section{Image acquisition}

All images were obtained using an Olympus BX51M optical microscope (200× optical magnification) fitted with an Olympus E-510 digital single lens reflex camera $(3648 \times 2736$ pixels, resolution of 9.98 megapixels, exposure time of $1 / 50$, ISO 100 , white balance of $3200 \mathrm{~K}$, image acquired in dark field using a $12 \mathrm{~V} / 100 \mathrm{~W}$ halogen light source). We used QuickPhoto Micro 2.3 commercial software with the Deep Focus 3.1 module (Promicra, s.r.o.) to obtain images with a high depth of focus (to reduce image blurring).

The AK scaffold was cut across its center and monitored in each centric segment (Fig. 1a and Fig. 1e), the NF scaffold was monitored along the entire length $(20 \mathrm{~cm}$, Fig. $1 \mathrm{~b}$ and Fig. 1f). The given section of the scaffold with bacterial biofilm was deposited onto a microscope slide with no staining and only native samples were observed. Three sets of approximately 20 images per $\mathrm{AK}$ scaffold were acquired in each segment, a set of approximately 60 images was taken for each $20 \mathrm{~cm}$ of thread on the NF scaffold, during each observation period. The observed surface was $530 \times 400 \mu \mathrm{m}$. The whole biomass (live and dead cells, organic and inorganic matter, and extracellular material) was detected by the optical method. The scaffolds can be returned to the bioreactor without removing the biofilm, however, the microscopy must be performed in a short time e.g., within several minutes).

\section{Preprocessing and image enhancement}

Image preprocessing, enhancement, segmentation, and analysis were undertaken using a program developed within Matlab (The Mathworks, Inc.). Some corrections, such as image sharpening and adjustment of brightness and contrast, were applied in Matlab to all of the images, according to (Gonzalez and Woods 2007, Lewandowski and Beyenal 2013, Wu et al. 2008).

\section{Image segmentation and morphological processing}

The images were converted into the appropriate color model for the needed parameters evaluating (HSV 
color space $=$ hue, saturation, value, or grayscale or binary color space). Matlab was used to confirm that the region corresponding to bacterial biofilm was represented by saturation values greater than $40 \%$ in the image saturation layer (in HSV color space). The selected regions were subjected to segmentation and image thresholding, using the Otsu method (Wu et al. 2008). The biofilm characteristics (morphological parameters) were then calculated from these extracted regions (grayscale color space, for examples see Figs $1 \mathrm{~g}$ and $1 \mathrm{~h}$ ).

\section{Characterization of biofilm area}

In this study, a number of basic parameters were evaluated according to (Costa et al. 2013, Lewandowski and Beyenal, 2013, Li et al. 2019, Wu et al. 2008), i.e., the number of cell clusters (individual biofilm colonies), diameter of cell clusters, surface covering of the scaffold by the biofilm, and biofilm areal porosity. The biofilm volume (first units of $\mu \mathrm{m}$ due to the thin layer of biofilm) can be replaced with the surface area characterization (the surface covered by the bacterial biofilm).

\section{Results and Discussion}

Input temperature, substrate load (COD), and
HRT values (Fig. 2a), along with output COD (Fig. 2b), were measured over a period of 120 days. The efficiency of COD removal was monitored as a crucial parameter to ensure the steady state conditions of the bioreactors. Reactor operation was evaluated after steady state was reached (at least two weeks after changing the concentration or amount of wastewater supplied). The critical concentration for toxic contaminants cannot be exceeded in the reaction mixture, therefore, the adaptation was very slow, and HRT increased gradually based on the actual concentration of COD in the bioreactors.

There was a pronounced difference between the two carriers examined, where NF structure was clearly more suitable scaffold both at the beginning of the experiment (prior to massive immobilization at around 15 days) and at the end (maximum bioreactor loading at around 80 days onwards).

\section{Number of individual colonies identified on the scaffold}

The individual cells attach a surface and form a coherent (mono)layer and create colonies (cell clusters). We used the term 'colony' to mean either a single colony or a group of conjoined colonies (cell clusters) on the biofilm separated by interstitial voids (Lewandowski and

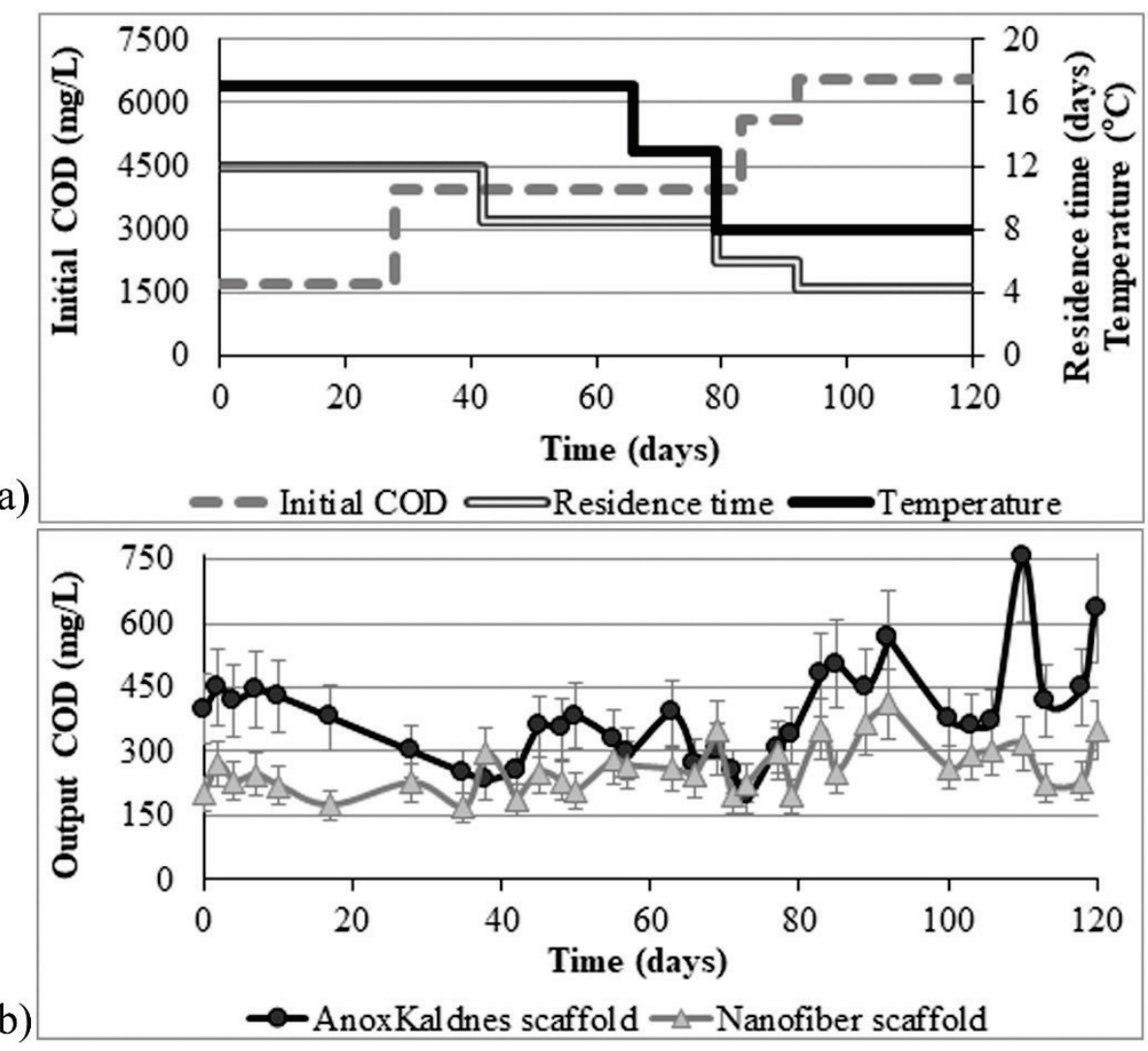

Fig. 2. a) Input (COD, HRT, Temperature); b) output (COD) parameters for the AnoxKaldnes (AK) and nanofiber (NF) scaffolds over the 120-day experimental period. 
Beyenal 2013). The surface properties determines the adhesion of cells to the scaffold especially the growth rate and growth stability (Leyva-Díaz et al. 2017, Pandey et al. 2018, Veerachamy et al. 2014). Subsequently, the number of cell clusters per scaffold surface area tends to decline over time depending on the culture conditions. The smaller cell clusters gradually agglomerate to form larger units that may end up covering the whole surface of the scaffold (i.e., the number of cell clusters will equal one by the end of the colonization process). Our measurements tend to support this assumption, but only for the commercial AK scaffold.

At the beginning of the experiment, approximately 330 cell clusters $/ \mathrm{mm}^{2}$ were identified on the AK scaffold (the minimum size of a cell cluster was $3.0 \mu \mathrm{m}$ ), this number changing very little over the first two weeks (Fig. 3a). During this primary colonization, bacteria must generate the EPS that protect them during fixed attaching to surface (ensures the structural integrity of the biofilm), following which large-scale colonization can take place (Veerachamy et al. 2014). Extensive coloni-zation of the AK scaffold's surface took place between the $14^{\text {th }}$ and $60^{\text {th }}$ day of cultivation (Fig. 3a), during which growth of the secondary biofilm stage proceeded much quicker as it was easier for the cells to adhere the previously established primary biofilm layer. Extensive colonization also occurred due to increase in inlet COD values or due to reduction of the residence time (Fig. 2a), adverse environmental conditions result in faster colonization and biofilm formation. From the $60^{\text {th }}$ day onwards, the number of cell clusters tended to decrease as the biofilm merged into larger units (mature biofilm, Fig. 3b), these merged colonies were able to produce the biofilm faster than the smaller individual colonies.

In comparison, 1900 cell clusters $/ \mathrm{mm}^{2}$ were identified on the NF scaffold at the end of the first day (Fig. 3a), which is 5.75 times more as identified on the AK scaffold (330 cell clusters $/ \mathrm{mm}^{2}$ ). Nanofibers provide a structurally varied surface (high specific surface area, high porosity, and small [nano-scale] pore size) for the bacteria compared to the AK scaffold (Janoušková 2018, Pandey et al. 2018). Hence, cells that attach to the NF scaffold are immediately able to form fixed attachment without EPS help and thus create large flat units (Fig. 3b and $3 \mathrm{~d}$ ). The number of cell clusters decreases with time from the start of the experiment as the creation of a primary biofilm on the nanofiber's surface is not required. While the biofilm colonizes the NF scaffold first, it continues to grow and gradually extends to places without NF, hence, the surface-covering curve may oscillate slightly.

By the end of the experiment, the AK scaffold supported 1400 and the NF scaffold 200 cell clusters $/ \mathrm{mm}^{2}$ (Fig. 3a). In general, we would expect the number of cell clusters to fall to one (Leyva-Díaz et al. 2017, Veerachamy et al. 2014). Hence, the higher numbers observed for both scaffolds suggest that the colonization process had not finalized by the end of observation.

\section{Scaffold surface covering by the biofilm}

Surface covering curves (Fig. 3b) show a growing tendency, with speed and stability dependent
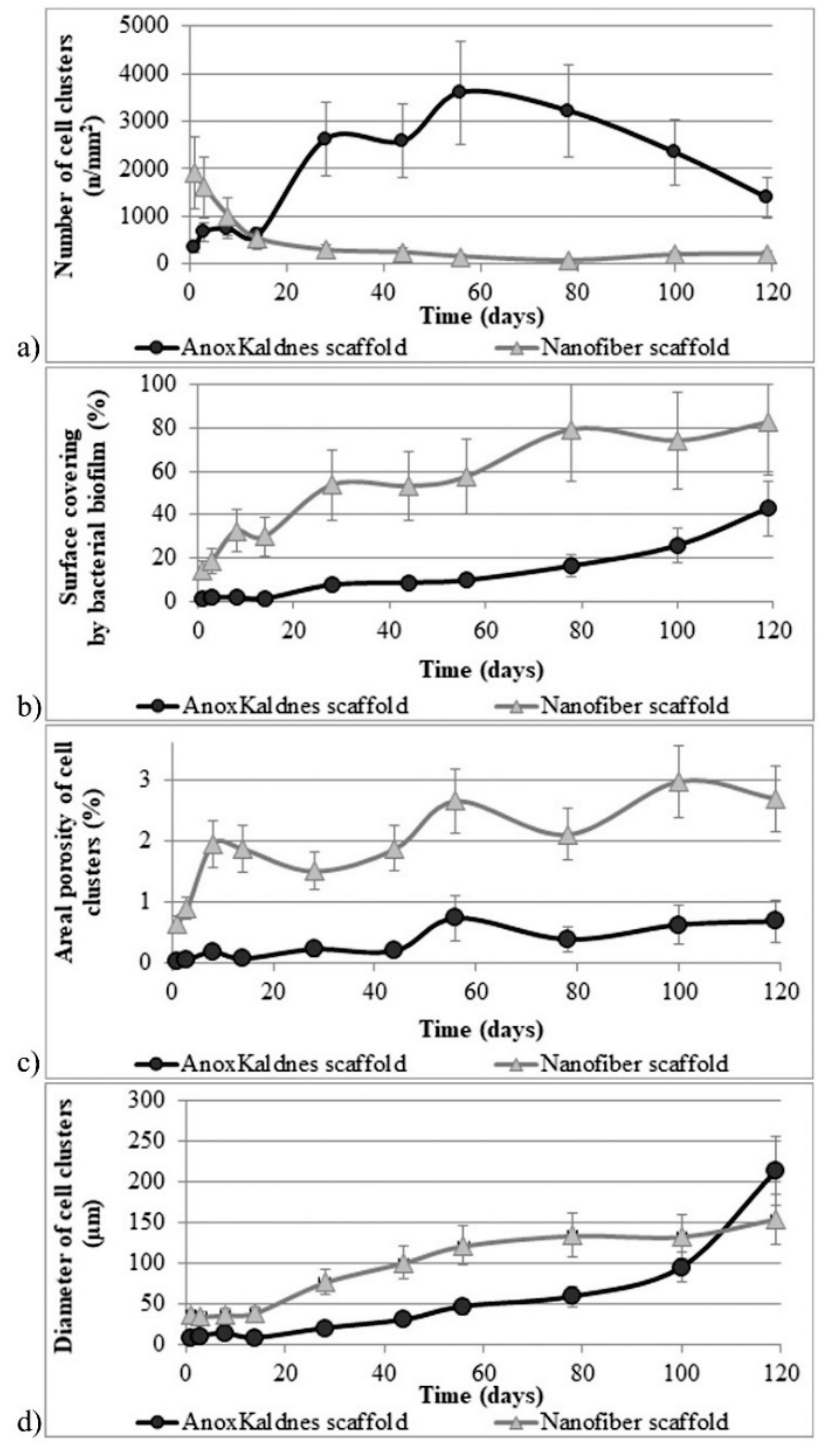

Fig. 3. a) Number of individual colonies (cell clusters); b) surface covering by bacterial biofilm; c) areal porosity of cell clusters; d) diameter of cell clusters on AK and NF scaffolds over 120 days. (Note: areal porosity of zero indicates that the biofilm is completely compact, i.e., without voids, increasing areal porosity values indicate increasing probability of voids and channels in the biofilm). 
mostly on the nature of the scaffold, the cell population, and system condition (Azeredo et al. 2017). The biomass growth is very slow due to the composition of medium (cresols as a carbon source are degrading very slowly) and due to the applied high aeration intensity (high shearing forces). The aim of the experiment was to create a thin and thus active and effective biofilm (Ødegaard, 2006).

Over the first 14 days of testing, no noticeable scaffold colonization was observed on the AK scaffold (Fig. 3b). The number of cell clusters on the AK scaffold was relatively constant and this correlates with a process of zero increase on the surface covering. Massive biofilm development did not occur until the $60^{\text {th }}$ day of colonization (Fig. 3b). By the end of the colonization, the mature biofilm covered approximately $40 \%$ of the AK scaffold surface. Surface covering growth curves for the AK scaffold were consistent with the literature, where growth curves valid for a low rate of substrate loading were observed (Liu et al. 2010).

For the NF scaffold, the number of cell clusters decreased markedly at the beginning of the experiment (Fig. 3a), along with a simultaneous increase in surface covering (Fig. 3b). This process indicates permanent capture and immediate secondary biofilm formation on the NF scaffold. The surface-covering curve was steeper than that of the AK scaffold, indicating rapid and easier colonization of the NF scaffold's surface. By the end of the experiment, the mature biofilm covered more than $80 \%$ of the NF scaffold surface.

\section{Biofilm areal porosity}

Biofilm matter are inconsistent and non-uniform, the pores hold or channel a large amount of the fluid flowing through the biofilm (Azeredo et al. 2017, Veerachamy et al. 2014). In this paper, biofilm areal porosity is defined as the ratio of the internal void area in the biofilm (void pixels, pores) to the total biofilm area (total number of pixels, pores plus biofilm matter).

The biofilm areal porosity was equal or close to zero on the AK scaffold at the beginning of the experiment (Fig. 3c). The initially formed cell clusters presented a low or zero areal porosity, however, as the cell cluster size increased over time (Fig. 3d) the biofilm areal porosity also increased (Wang et al. 2014). By the end of the experiment, the average biofilm areal porosity for the AK biofilm scaffold was $0.68 \%$, with a maximum value of around $1.03 \%$.

Initial cell clusters on the NF scaffold were not completely solid, resulting in areal porosity of $0.64 \%$ (Fig. 3c). The biofilm areal porosity increased with increasing cell cluster size (Fig.s $3 \mathrm{c}$ and $3 \mathrm{~d}$ ), resulting in a mean areal porosity of $2.68 \%$ (with a maximum of $3.56 \%$ ) by the end of the experiment. The biofilm areal porosity for the NF scaffold was 4.6 times higher on average than that of the AK scaffold. The cell clusters on the NF scaffold tended to be larger, moreover, these clusters contain voids that grew in size simultaneously over time.

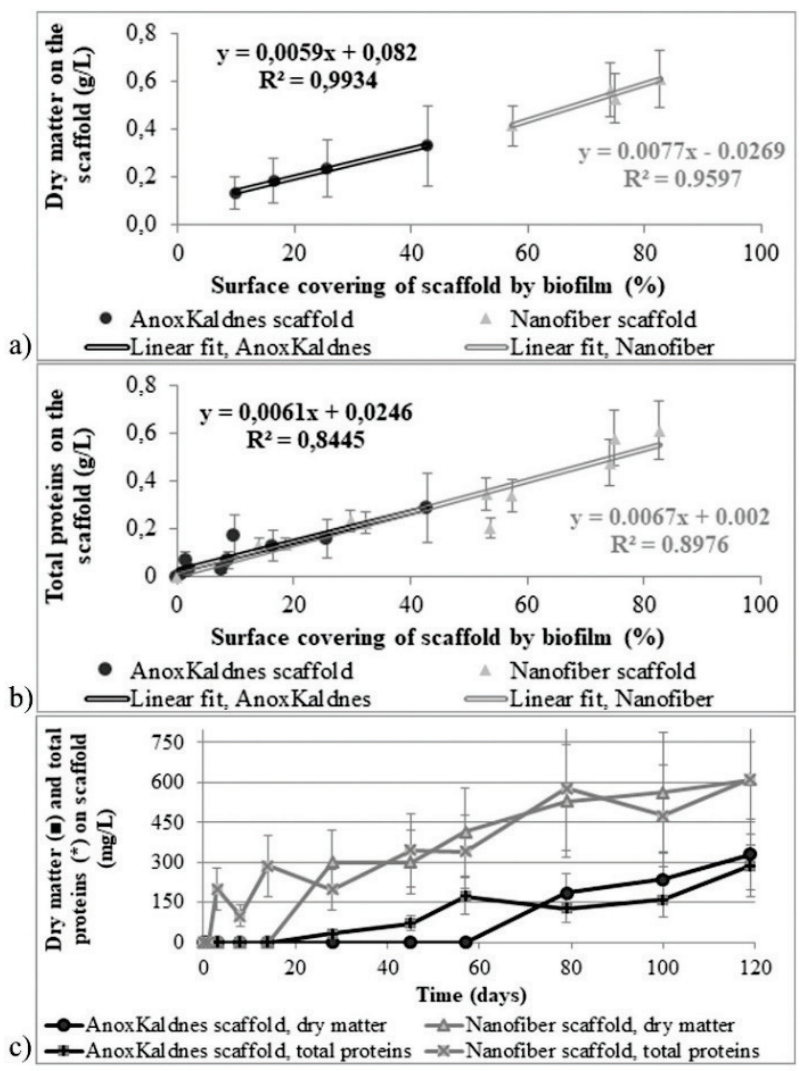

Fig. 4. a) The correlation between dry matter and biofilm growth (surface covering of scaffold indicated by image analysis); b) correlation between proteins and biofilm growth (surface covering of scaffold indicated by image analysis); c) comparison of dry matter and protein determination growth curves.

Correlation of image analysis with determination of dry matter

The rate of surface covering on the two scaffolds (Fig. 3b) correlate strongly with the results for the determination of dry matter $\left(\mathrm{R}_{\mathrm{AK}}^{2}=0.99\right.$ and $\mathrm{R}_{\mathrm{NF}}^{2}=0.96$, Fig. 4a). The $R^{2}$ values were obtained from four data points, where each point is the average of three parallel measurements. Note that it was only possible to assess the increase in dry matter from the $56^{\text {th }}$ day onwards for $\mathrm{AK}$ and from $21^{\text {th }}$ day onwards for NF (Fig. 4c). It was 
not possible to determine the weight by gravimetric measurement due to the very low weight of biofilm on the scaffold prior to these points. While image analysis can be employed even in the early stages of biofilm growth, dry matter can only be determined once there is a sufficient amount of biofilm on the scaffold (the sensitivity of our method was from $80 \mathrm{mg} / \mathrm{l}$ ).

Correlation of image analysis with (total) protein measurements

Analysis of total protein evolution indicates an increasing tendency throughout the 120-day observation period, approach sensitivity can be seen from $20 \mathrm{mg} / \mathrm{l}$. The trend in the total protein growth well correlated with the rate of surface covering obtained through image analysis $\left(\mathrm{R}^{2}{ }_{\mathrm{AK}}=0.84\right.$ and $\mathrm{R}_{\mathrm{NF}}^{2}=0.89$, Fig. 4d). The $\mathrm{R}^{2}$ values were obtained from 11 data points, where each point is the average of three parallel measurements. The overall biofilm protein determination performed in parallel with the image analysis summarizes the undergoing changes in the total protein of the attached dividing/resting cells, including the protein released by the cell lysis process.

\section{Conclusions}

Comparative study of two types of biofilm carriers showed the clear advantages of nanofiber scaffold (higher porosity, size, and number of bacterial colonies on nanofiber's surface), which support the growth of microorganisms in the forms of biofilm. The most important advantage is an increasing speed of primary surface colonization (up to four times faster), which shortens the time required for the areal biofilm formation and optimum performance of attached microorganisms (higher efficiency of biological activity of up to twice as fast, high performance biofilm on nanofiber). Experimental study confirmed higher stability of microbial biofilm formed on nanofiber surface (the amount of attached biofilm oscillates less), which has a potential for different biotechnologies implicating biofilm as a decisive biomass in the system (like wastewater treatment, food biotechnology, pharmacology etc.).
Image analysis of microbial biofilm was confirmed as an effective tool for advanced characterization of the biofilm natural growth. This method is noninvasive and very valuable especially for the evaluation of early stages of the biofilm (even at the beginning of the process), where common gravimetric method is inapplicable. Moreover, image analysis makes it possible to get much more information about the biofilm structure like number and size of cell clusters during initial phase of biofilm development and about the porosity of the biofilm, which is crucial at the time when mature biofilm is created. This advantage is highlighted in the case of slowly growing microorganisms when the only carbon source is toxic or slowly degradable compound like the cresols. Image analysis has the potential to evaluate and predict the biofilm development and to identify possible abnormal stages.

\section{Conflict of Interest}

There is no conflict of interest.

\section{Acknowledgments}

This work was supported by the Ministry of Education, Youth and Sports of the Czech Republic and The European Union - European Structural and Investments Funds in the frame of Operational Programme Research Development and Education - project Pro-NanoEnviCz (Project No. CZ.02.1.01/0.0/0.0/16_013/0001821).

This publication was written at the Technical University of Liberec as part of the project "The study and evaluation of the structure and properties of metallic and non-metallic materials" with the support of the Specific University Research Grant, as provided by the Ministry of Education, Youth and Sports of the Czech Republic in the year 2019.

We would like to thank Kevin Roche and Craig Hampson for their help with English language correction.

\section{Abbreviations}

AK, AnoxKaldnes; COD, chemical oxygen demand; EPS, Extracellular polymeric substance; HRT, hydraulic residence time; NF, nanofiber.

\section{References}

AZEREDO J, AZEVEDO NF, BRIANDET R, CERCA N, COENYE T, COSTA AR, DESVAUX M, DI BONAVENTURA G, HÉBRAUD M, JAGLIC Z, KAČÁNIOVÁ M, KNØCHEL S, LOURENÇO A, MERGULHÃO F, MEYER RL, NYCHAS G, SIMÕES M, TRESSE O, STERNBERG C: Critical review on biofilm methods. Crit Rev Microbiol 43: 313-351, 2017. 
COSTA JC, MESQUITA DP, AMARAL AL, ALVES MM, FERREIRA EC: Quantitative image analysis for the characterization of microbial aggregates in biological wastewater treatment: a review. Environ Sci Pollut Res 20: 5887-5912, 2013.

GONZALEZ RC, WOODS RE: Digital Image Processing, 3rd ed., Prentice Hall, Upper Saddle River, N.J., 2007.

HABIMANA O, SEMIÃO AJC, CASEY E: The role of cell-surface interactions in bacterial initial adhesion and consequent biofilm formation on nanofiltration/reverse osmosis membranes. J Membr Sci 454: 82-96, 2014.

HADJIEV D, DIMITROV D, MARTINOV M, SIRE O: Enhancement of the biofilm formation on polymeric supports by surface conditioning. Enzyme Microb Technol 40: 840-848, 2007.

HAIDER A, HAIDER S, KANG IK: A comprehensive review summarizing the effect of electrospinning parameters and potential applications of nanofibers in biomedical and biotechnology. Arab J Chem 11: 1165-1188, 2018.

JANOUŠKOVÁ O: Synthetic polymer scaffolds for soft tissue engineering. Physiol Res 67: 335-348, 2018.

JIRSÁK O, SANETRNÍK F, LUKÁŠ D, KOTEK V, MARTINOVÁ L, CHALOUPEK J: A Method of Nanofibres Production from a Polymer Solution Using Electrostatic Spinning and a Device for Carrying Out the Method, [online] Available from: https://patentscope.wipo.int/search/en/detail.jsf?docId=WO2005024101 (Accessed 17 May 2016), 2005

JIRSÁK O, SANETRNÍK F, CHALOUPEK J: Nanofiber-covered yarns. Chem Fibers Int 61: 84-86, 2011.

JURECSKA L, BARKÁCS K, KISS É, GYULAI G, FELFÖLDI T, TÖRÖ B, KOVÁCS R, ZÁRAY G: Intensification of wastewater treatment with polymer fiber-based biofilm carriers. Microchem J 107: 108-114, 2013.

LEWANDOWSKI Z, BEYENAL H: Fundamentals of Biofilm Research, 2nd ed., CRC Press, 2013.

LEYVA-DÍAZ JC, MARTÍN-PASCUAL J, POYATOS JM: Moving bed biofilm reactor to treat wastewater. Int $J$ Environ Sci Technol 14: 881-910, 2017.

LI C, WANG K, XU N: A survey for the applications of content-based microscopic image analysis in microorganism classification domains. Artif Intell Rev 51: 577-646, 2019.

LIU Q, WANG XC, LIU Y, YUAN H, DU Y: Performance of a hybrid membrane bioreactor in municipal wastewater treatment. Desalination 258: 143-147, 2010.

ØDEGAARD H: Innovations in wastewater treatment: the moving bed biofilm process. Water Sci Technol J Int Assoc Water Pollut Res 53: 17-33, 2006.

O'GORMAN L, SAMMON MJ, SEUL M: Practical Algorithms for Image Analysis with CD-ROM, 2nd ed., Cambridge University Press, Cambridge; New York, 2008.

PANDEY S, RATHORE K, JOHNSON J, CEKANOVA M: Aligned nanofiber material supports cell growth and increases osteogenesis in canine adipose-derived mesenchymal stem cells in vitro. J Biomed Mater Res A 106: 1780-1788, 2018.

SINGH S, SINGH SK, CHOWDHURY I, SINGH R: Understanding the mechanism of bacterial biofilms resistance to antimicrobial agents. Open Microbiol J 11: 53-62, 2017.

SIPMA J, OSUNA MB, EMANUELSSON MAE, CASTRO PML: Biotreatment of industrial wastewaters under transient-state conditions: process stability with fluctuations of organic load, substrates, toxicants, and environmental parameters. Crit Rev Environ Sci Technol 40: 147-197, 2010.

SONKA M, HLAVAC V, BOYLE R: Image Processing, Analysis, and Machine Vision. 3rd ed., Cengage Learning, Toronto, 2007.

VEERACHAMY S, YARLAGADDA T, MANIVASAGAM G, YARLAGADDA PK: Bacterial adherence and biofilm formation on medical implants: A review. Proc Inst Mech Eng 228: 1083-1099, 2014.

WANG C, MIAO L, HOU J, WANG P, QIAN J, DAI S: The effect of flow velocity on the distribution and composition of extracellular polymeric substances in biofilms and the detachment mechanism of biofilms. Water Sci Technol 69: 825-832, 2014.

WU Q, MERCHANT F, CASTLEMAN K: Microscope Image Processing, 1 edition, Academic Press, Amsterdam; Boston, 2008. 